\title{
Analisis Makna Kontekstual Pada Iklan Televisi
}

\section{Tri Pujiatna ${ }^{a, 1}$, Jaja ${ }^{\text {a,2, }}$, dan Anggi Krisma Diana ${ }^{\text {a,3 }}$}

anniversitas Swadaya Gunung Jati, Cirebon

Itpujiatna@gmail.com; ${ }^{2} j a j a w i l a s a @ g m a i l . c o m ; 3$ krimadiana25@yahoo.com

\begin{tabular}{|c|c|}
\hline Article info & A B S T R A C T \\
\hline $\begin{array}{l}\text { Article history: } \\
\text { Received: } 29-11-2018 \\
\text { Revised : 02-09-2019 } \\
\text { Accepted:08-10-2019 }\end{array}$ & $\begin{array}{l}\text { Human life today is inseparable from the influence of } \\
\text { television. Various information can be obtained quickly. To } \\
\text { meet the entertainment needs of humans/television viewers, } \\
\text { television always inserts advertisements. Besides having } \\
\text { commercial purposes, advertising also has the value of the } \\
\text { information contained in it. Advertisers, both private and } \\
\text { government, try to introduce and invite the public to do } \\
\text { what the advertiser wants. Advertisers try to convey } \\
\text { messages to consumers or the public in the form of } \\
\text { meaningful symbols through mass media which are usually } \\
\text { in the form of television, radio, and newspapers. The symbol } \\
\text { of meaning is language. Language is used as a } \\
\text { communication tool in advertising even though there are } \\
\text { many other communication tools, such as images and } \\
\text { sounds. The shape of the symbol, namely the language used } \\
\text { as a communication tool in advertising has its own meaning. }\end{array}$ \\
\hline $\begin{array}{l}\text { Keywords: } \\
\text { advertising } \\
\text { communication } \\
\text { convey messages } \\
\text { human life } \\
\text { television }\end{array}$ & $\begin{array}{l}\text { Kehidupan manusia saat ini tidak terlepas dari pengaruh } \\
\text { televisi. Berbagai informasi dapat diperoleh dengan cepat. } \\
\text { Untuk memenuhi kebutuhan hiburan manusia/pemirsa } \\
\text { televisi, televisi selalu menyisipkan tayangan iklan. Di } \\
\text { samping memiliki tujuan komersil, iklan juga memiliki nilai } \\
\text { informasi yang terkandung di dalamnya. Para pengiklan } \\
\text { baik swasta maupun pemerintah berusaha untuk } \\
\text { memperkenalkan serta mengajak masyarakat dapat } \\
\text { melakukan apa yang diharapkan oleh pembuat iklan. } \\
\text { Pembuat iklan berusaha untuk menyampaikan pesan kepada } \\
\text { konsumen atau masyarakat dalam bentuk lambang } \\
\text { bermakna melalui media massa yang biasanya berupa } \\
\text { televisi, radio dan surat kabar. Lambang makna yang } \\
\text { dimaksud adalah bahasa. Bahasa digunakan sebagai alat } \\
\text { komunikasi dalam periklanan walaupun masih banyak lagi } \\
\text { alat komunikasi yang lain, seperti gambar, dan bunyi. } \\
\text { Bentuk lambang yaitu bahasa yang digunakan sebagai alat } \\
\text { komunikasi dalam periklanan memiliki makna tersendiri. } \\
\text { Copyright } 92019 \text { Institut Agama Islam Negeri Syekh Nurjati Cirebon. } \\
\text { All rights reserved. }\end{array}$ \\
\hline
\end{tabular}

\section{PENDAHULUAN}

Iklan merupakan bagian yang tak terpisahkan dari media pertelevisian. Kehidupan manusia saat ini tidak terlepas dari pengaruh televisi. Berbagai 
informasi dapat diperoleh dengan cepat. Untuk memenuhi kebutuhan hiburan manusia atau pemirsa televisi, televisi selalu menyisipkan tayangan iklan. Disamping memiliki tujuan komersil, iklan juga memiliki nilai informasi yang terkandung di dalamnya. Para pengiklan, baik swasta maupun pemerintah berusaha untuk memperkenalkan serta mengajak masyarakat dapat melakukan hal yang diharapkan oleh pembuat iklan. Iklan melalui televisi memiliki berbagai kelebihan dibandingkan dengan jenis media lainnya yang mencakup daya jangkauan luas selektivitas dan fleksibilitas, fokus perhatian, kreativas dan efek, prestise, serta waktu tertentu (Andrianto, 2018).

Iklan adalah alat (Sukirno, 2004). Iklan digunakan sebagai alat untuk memperkenalkan barang atau jasa kepada masyarakat dan membujuk agar mau membelinya. Iklan televisi sangat beraneka ragam dan dibuat semenarik mungkin demi tersampaikannya maksud dan tujuan dari iklan tersebut. Dari mulai yang bersifat bisnis, sosial, politik atau lainnya. Tujuan iklan bukan hanya sebagai media penawaran produk, iklan juga turut berpengaruh dalam membentuk gaya hidup, kebiasaan, selera dan jati diri seseorang masyarakat itu sendiri. Iklan merupakan kampanye sosial yang bertujuan untuk mempromosikan gagasan atau ide bagi kepentingan atau pelayanan masyarakat (Kosasih, 2014). Tujuan iklan tergantung pada konteks kegiatan. Tujuan tersebut dapat bersifat bisnis, sosial, politik atau lainnya.

Iklan memiliki peran penting sebagai alat komunikasi. Iklan merupakan alat paling efektif dalam menjangkau sebanyak mungkin konsumen serta untuk mengingatkan konsumen mengenai wujud barang yang diiklankan. Selain berfungsi sebagai alat pengaruh, iklan berfungsi sebagai suatu alat penyampaian informasi baik mengenai barang, jasa maupun informasi lainnya yang berkaitan dengan khalayak ramai. Pembuat iklan berusaha untuk menyampaikan pesan kepada konsumen atau masyarakat dalam bentuk lambang bermakna melalui media massa yang biasanya berupa televisi, radio, dan surat kabar. Lambang makna yang dimaksud adalah bahasa. Bahasa digunakan sebagai alat komunikasi dalam periklanan walaupun masih banyak lagi alat komunikasi yang lain, seperti: gambar, dan bunyi. Bentuk lambang yaitu bahasa yang digunakan sebagai alat komunikasi dalam periklanan memiliki makna tersendiri. Perwujudan makna digunakan untuk menyampaikan informasi sehingga dapat saling dimengerti 
(Sugiantomas, dkk., 2017). Oleh karena itu, seorang konsumen iklan harus mampu mengartikan makna atau informasi yang terdapat dalam sebuah iklan.

Bahasa merupakan bentuk kreativitas antara pemakai dengan lingkungannya. Bahasa berfungsi sebagai alat untuk komunikasi, baik tulis maupun verbal. Sebagai alat komunikasi, bahasa memiliki peran yang sangat penting dan multiperan dalam berbagai lini kehidupan. Widijayanto (2015) bahasa merupakan media komunikasi yang paling efektif yang dipergunakan oleh manusia untuk berinteraksi dengan individu lainnya. Oleh karena itu, pengguna bahasa harus mampu menggunakannya dengan baik. Hal ini perlu dipahami karena bahasa tidak terlepas dari sebuah makna. Bahasa sebagai wahana komunikasi dalam hubungan sosial maupun formal. Oleh karena itu, sudah seharusnya pemakai bahasa mulai dari tingkat dasar sampai dengan tingkat perguruan tinggi menunjukkan kemantapan dalam berbahasa.

Juniarti \& Wahyuniarti (2019) mengaitkan bahasa sesuai ruang dan waktu sehingga situasi pengungkapan dan pemahaman berbahasa akan dihasilkan alat ucap manusia. Hal ini membuktikan bahwa bahasa dan makna tidak dapat dipisahkan. Bahasa dan makna merupakan satu kesatuan dari suatu proses komunikasi. Azhari (2014) proses komunikasi diartikan sebagai transfer informasi atau pesan dari pengirim pesan sebai komunikator dan kepada penerima sebagai komunikan. Antara komunikator dan komunikan akan saling memahami maksud dan tujuannya, keduanya harus mampu menggunakan bahasa yang baik dan benar.

Makna merupakan persoalan yang menarik dalam kehidupan sehari-hari seseorang berbicara kepada orang lain tentulah terkandung sebuah makna dibalik bahas yang dituturkan (Palimbong, 2015). Menurut Aminuddin (2013), makna merupakan hubungan antara bahasa dengan dunia luar yang disepakati oleh beberapa pengguna bahasa sehingga memiliki arti di dalamnya. Hal ini membuktikan bahwa makna tidak selalu berkaitan dengan dunia dalam bahasa saja, melainkan dari luar dunia bahasa pun dilihat keberadaannya. Setiap makna erat dengan konteks. Makna kontekstual muncul sebagai akibat antara ujaran dan situasi pada waktu ujaran dipakai.

Konteks merupakan kondisi di mana suatu keadaan terjadi. Lewandoski (Jauhar, 2013) konteks mempunyai dua pengertian, yaitu sebagai konteks bahasa dan konteks luar bahasa. Konteks bahasa ialah konteks yang ruang lingkupnya 

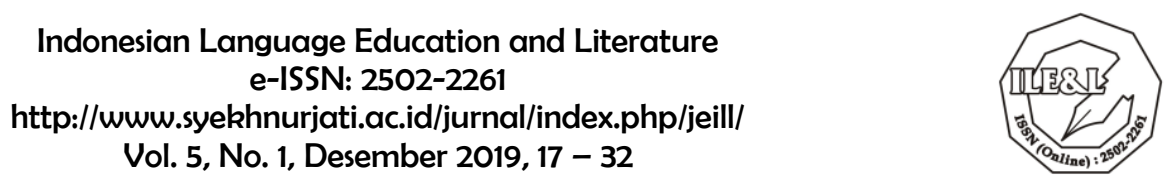

terletak pada bahasa (linguistik) yang memiliki aturan tetap dan unsur-unsur bahasa untuk memengaruhi pemahaman makna. Sementara konteks luar bahasa adalah suatu konteks faktor luar bahasa yang biasanya meliputi suatu pernyataan. Konteks ini juga disebut konteks komunikatif yang penggunaannya dipengaruhi oleh pengetahuan luar bahasa dan pemakaian unsur-unsur bahasa dalam suatu teks atau ujaran. Sebuah konteks memiliki keterkaitan yang erat dengan suatu makna. Ketika akan menganalisis makna, salah satu yang dilihat ialah konteksnya. Jadi, konteks dalam suatu wacana atau situasi penting diperhatikan.

Kontekstual mengisyaratkan bahwa sebuah kata atau simbol ujaran tidak mempunyai makna jika terlepas dari konteks. Kontekstual merupakan satu situasi yang terbentuk karena terdapat setting, kegiatan dan relasi. Konteks akan terbentuk jika antara tiga komponen itu saling berinteraksi. Komponen setting meliputi waktu dan tempat situasi terjadinya peristiwa berbahasa (Parera, 2004). Setting terdiri atas (1) unsur-unsur material yang ada di sekitar interaksi berbahasa, (2) tempat, yakni tata letak dan tata atur barang dan orang, serta (3) waktu, yakni pengaturan urutan waktu dalam peristiwa interaksi berbahasa. Makna kontekstual adalah makna leksem atau kata yang berada di dalam satu konteks (Chaer, 2009). Makna konteks dapat pula berkenaan dengan situasinya yakni tempat, waktu, dan lingkungan penggunaan bahasa itu.

Ketika mengekspresikan suatu gagasan dalam berbagai bentuk bahasa harus memilih kata-kata dan memiliki strategi untuk menyajikan kata-kata itu agar gagasan tersampaikan dengan baik. Pilihan kata dan strategi penyajian kata-kata tersebut sangat ditentukan oleh tujuan dan situasi (konteks). Peristiwa berbahasa adalah proses sosial yang berorientasi pada tujuan sosial tertentu dan dalam konteks situasi tertentu pula.

Peristiwa berbahasa dapat dikaji dengan ilmu semantik melalui telaah makna kontekstual. Di mana makna kontekstual dapat diartikan sebagai makna kata atau leksem yang berada pada suatu uraian atau kalimat yang dapat mengandung atau menambah kejelasan makna, yang dipengaruhi oleh situasi, tempat, waktu, dan lingkungan penggunaan kata tersebut. Artinya, munculnya makna kontekstual bisa disebabkan oleh situasi, tempat, waktu, dan lingkungan. Atau lebih jelasnya makna kontekstual muncul sebagai akibat hubungan antara ujaran dan konteks. 
Sukrajap (2013) Iklan merupakan salah satu alat promosi yang paling banyak digunakan perusahaan untuk menginformasikan, membujuk, dan mengingatkan pembeli sasaran atau masyarakat mengenai keberadaan suatu produk atau jasa yang pada akhirnya dimaksudkan untuk meningkatkan penjualan. Artiya Iklan merupakan suatu bentuk promosi dengan tujuan utama iklan adalah menjual produk, jasa atau ide. Hal ini sejalan dengan Sutiyono \& Sutrimah (2016). Iklan merupakan suatu alat yang cukup tepat untuk mempromosikan produk dari sebuah perusahaan untuk kemudian dikenal oleh masyarakat luas dan kemudian agar memberikan pengaruh yang signifikam dan menarik perhatian.

Azhari (2014) iklan sebagai sebuah teks merupakan sistem tanda terorganisir menurut kode-kode yang mereflekasikan nilai-nilai tertentu, sikap dan juga keyakinan tertentu. Hal ini menunjukkan bahwa bahasa iklan merupakan suatu sistem yang terencana agar pesan yang ingin disampaikan dapat diterima dengan baik. Bahasa iklan harus ekspresif karena dia harus secara benar dan tepat mengungkapkan dengan istimewa pesan pesan yang ingin disampaikan (Suryanti, 2018).

Bahasa iklan adalah bahasa yang unik. Bahasa yang sengaja dibuat sedemikian rupa sehingga dapat memengaruhi calon konsumennya. Bahasa iklan digunakan untuk meresentasikan dari produk yang ditawarkan. Bahasa iklan akan memengaruhi terhadap produk, jasa atau ide yang ditawarkan. Tasruddin (2015) iklan akan mengalami proses pemasaran lebih kondusif apabila pihak perusaahaan periklanan maupun media massa memiliki preferensi yang tetap dalam memahami urgensi kegiatan promosi terhadap keberhasilan "menjual iklan" ke konsumen. Artinya bahwa bahasa iklan akan menentukan berhasil atau tidaknya terhadap produk yang ditawarkan kepada konsumen.

Bahasa dalam periklanan harus mampu bersinergi dengan produk yang ditawarkan. Bahasa iklan harus mampu mempunyai daya tarik tersendiri sebagai bentuk promosi. Kegiatan promosi dilakukan berusaha untuk membujuk calon konsumen untuk membeli produk yang ditawarkan yang berdampak pada hasil penjualan. Menurut Poluan, Lumintang, dan Untu (2016) menjelaskan bahwa strategi promosi akan mengingkatnya keputusan pembelian secara positf tentu akan berdampak pada meningkatnya volume penjulan produk, demikian juga sebaliknya. Hal ini menunjukkan bahwa bahasa iklan merupakan bagian dari 
strategi promosi. Agar promosi ini berjalan dengan efektif maka proses penyampaian produk juga harus efektif. Hendrastuti (2015) proses penyampaian penerimaan isi yang disampaikan berlangsung dengan sempurna apabila menggunakan kalimat yang efektif.

Promosi iklan membutuhkan strategi yang mantap. Salah satunya dengan menggunakan gaya bahasa. Kehadiran gaya bahasa menjadi sebagian kebutuhan dalam mengemas bahasa iklan yang menarik perhatian calon konsumen (Kuspriyono, 2015). Penggunaan gaya bahasa yang tepat akan menambah daya jual pada barang, jasa dan ide yang tawarkan. Hal ini sejalan dengan pendapat Musaffak (2015) penempatan susunan kata dan kalimat memberikan pengaruh yang sangat besar pada pemahaman pendengar, penyusunan bagian struktur iklan juga dapat mempengaruhi pendengar sehingga pendengar dapat terbujuk bahasa iklan. Artinya bahwa ketepatan dalam menggunakan bahasa iklan merupakan strategi promosi yang perlu dipertimbangkan.

\section{METODE}

Metode yang digunakan dalam penelitian ini adalah metode deskriptif. Pada penelitian ini penulis mendeskripsikan 5 iklan minuman dengan kajiaan telaah makna kontekstual. Dengan pemilihan metode ini diharapkan dapat memudahkan penulis dalam mencari data-data yang dibutuhkan secara sistematis, aktual dan akurat. Teknik yang digunakan dengan mendokumentasi 5 iklan minuman yang akan ditelitinya ke dengan mengunduh video iklan dari youtube yang kemudian dimanuskripkan serta dianalisis berdasarkan kajian telaah makna kontekstual.

Tujuan penelitian ini yaitu ingin mendokumentasikan keterkaitan antara iklan yang dibuat dengan makna konteksnya. Adapun sumber data pada penelitian ini adalah makna kontekstual pada iklan minuman yang bersumber dari media televisi periode tahun 2017-2018. Kriteria iklan minuman yang akan dianalisis dianggap memiliki makna kontektual.

\section{HASIL DAN PEMBAHASAN}

Adapun data pada penelitian tentang anailsis makna kontekstual ini berupa iklan minuman yang bersumber dari media televisi periode tahun 2017-2018. Data yang dipilih didasarkan pada keterkaitan antara iklan yang dibuat dengan 
kontekstualnya. Berikut data yang akan diteliti: 1) Le Mineral Versi Gerakan Indonesia Sehat, 2) Teh Botol Sosro versi Ramadan, 3) AQUA Versi Kemerdekaan RI-Rangkul Kebaikan, 4) Sprite Versi Ramadan, dan 5) You C1000 Versi Iris Mittenaere (Miss Universe 2016).

Berdasarkan data-data iklan televisi di atas, berikut hasil analisis makna kontekstual.

\section{a. Le Mineral Versi Gerakan Indonesia Sehat}

Slogan : Ayo dukung gerakan Indonesia sehat untuk Indonesia yang lebih sehat.

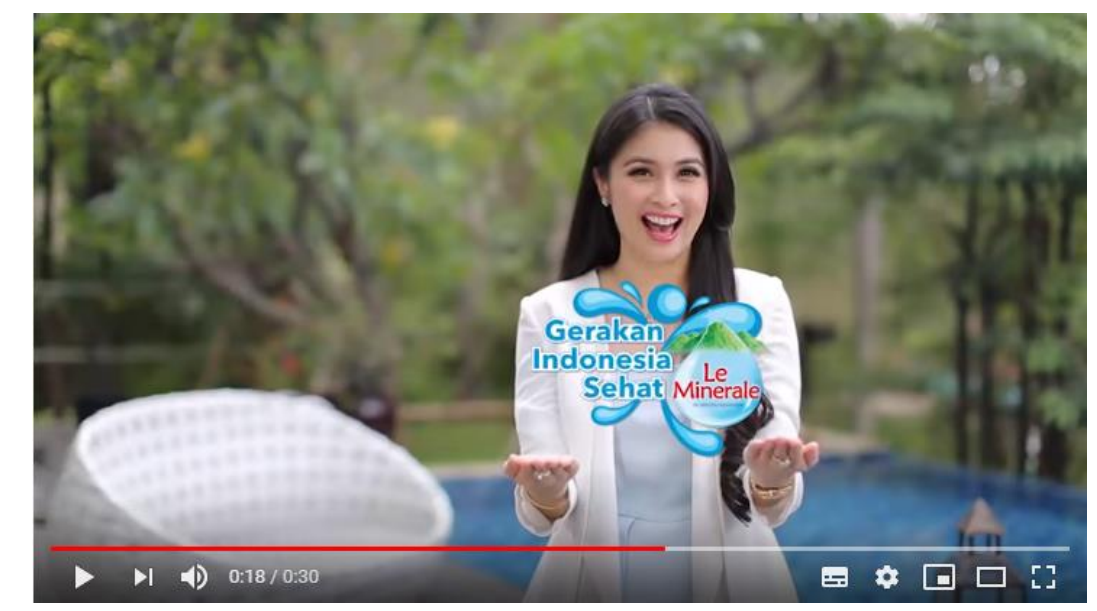

Situasi yang terlihat pada iklan Le Mineral versi Gerakan Indonesia Sehat memperlihatkan sekumpulan masyarakat dengan berbagai usia dan pekerjaan yang sedang melakukan senam bersama di salah satu tempat terbuka. Beberapa model iklan tersebut sedang menjawab beberapa pertanyaan yang diajukan. Iklan tersebut diambil pada waktu pagi hari dengan kondisi yang terlihat sangat ramai. Pada bagian awal iklan, dimulai dengan adegan Sandra Dewi selaku model pada iklan tersebut memberikan pertanyaan yang ditujukan kepada tiga orang lain yang ikut serta menjadi model iklan tersebut sekaligus penonton di rumah dengan pertanyaan berikut "Sudahkah anda menerapkan gaya hidup sehat?" yang kemudian disusul dengan jawaban dari tiga orang yang berbeda pada iklan tersebut sebagai berikut (1) belum sepenuhnya, (2) ga bisa dibilang sehat juga sih, dan (3) udah belum ya?. Selanjutnya Sandra dewi, sebagai model, menjelaskan bahwa lebih dari 50\% orang di Indonesia belum menerapkan gaya hidup yang sehat. Ia juga menjelaskan bahaya dari gaya hidup yang kurang sehat serta mengajak masyarakat untuk lebih sehat. Sandra 
dewi juga menjelaskan langkah-langkah untuk menjaga kesehatan dengan menyebutkan olahraga yang teratur, konsumsi makanan bergizi seimbang serta asupan mineral dengan air yang jelas mineralnya.

Berolahraga secara teratur merupakan cara yang paling penting dalam menjaga kesehatan tubuh. Setelah melakukan kegiatan berolahraga, seseorang pasti membutuhkan minum. Berolahraga merupakan pemicu keluarnya cairan/keringat lebih banyak. Berdasarkan kondisi ini, produk air dalam kemasan Le Minerale mempromisikan produknya agar dapat diterima oleh konsumennya yang diperkuat dengan adegan ketika para model meminum Le Mineral dan diiringi selingan kalimat "jaga asupan mineral dengan minuman yang jelas mineralnya" sambil memperlihatkan adegan seseorang yang sedang meminum produk Le Mineral. Mineral tidak diproduksi tubuh. Oleh karena itu, diperlukan asupan dari luar untuk memenuhi kebutuhan tubuh. Menurut dokter spesialis gizi, untuk memenuhi mineral dalam tubuh, sebaiknya mengonsumsi air putih untuk orang dewasa sebanyak 2 liter atau delapan gelas air putih, untuk orang lanjut usia sebanyak 1 liter sampai 1,5 liter atau empat sampai enam gelas sehari dan anak-anak dianjurkan mengonsumsi 1,6 liter sehari atau enam gelas sampai tujuh gelas.

\section{b. Teh Botol Sosro versi Ramadhan}

Slogan : Saat kalian mengaduh, ada yang tetap riang tanpa mengeluh Bagi sedikit yang kalian miliki untuk wujudkan sedikit harapan mereka.

Mari berkolaborasi \#HariUntukBerbagi klik www.tehbotolsosra.com

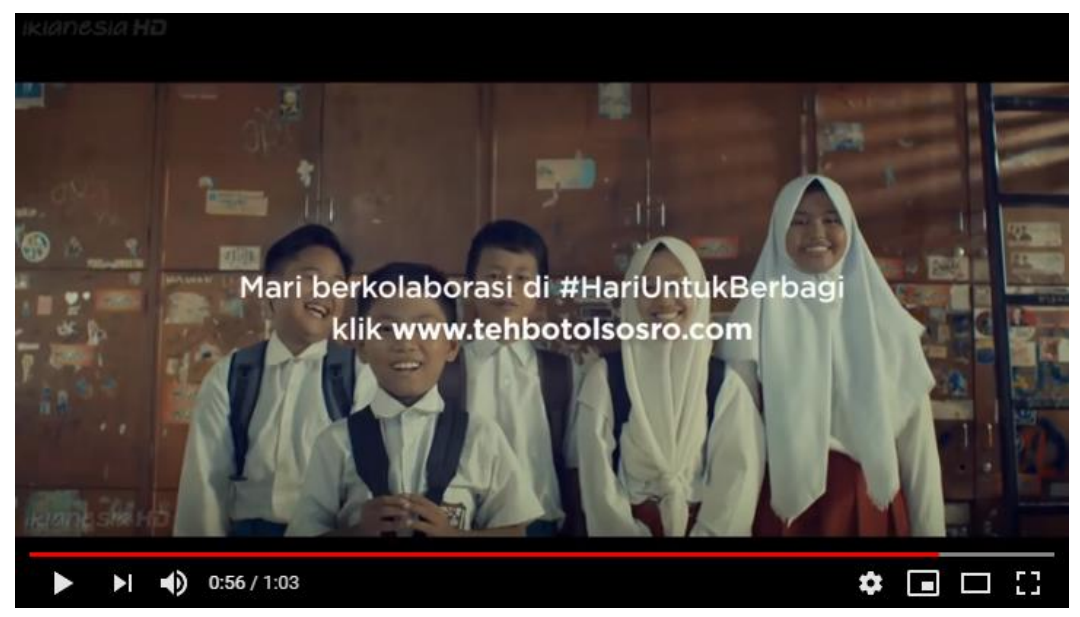

Adegan yang terlihat dari iklan Teh Botol Sosro ini sangat berbanding terbalik dengan apa yang diucapkan oleh dua model di iklan tersebut. Situasi 

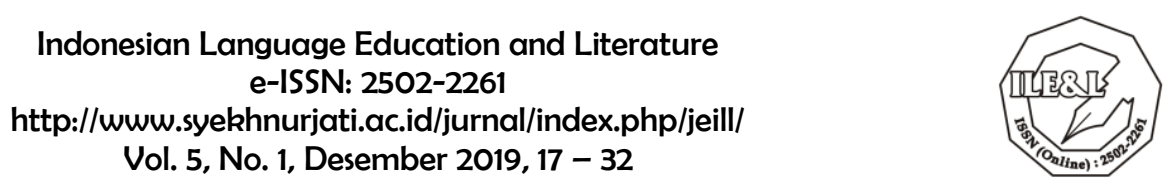

yang terlihat saat ke dua model tersebut mengeluhkan suasana dan makanan berbuka yang mereka rasakan diiklan tersebut justru malah memperlihatkan kebahagiaan dan keikhlasan anak-anak di panti asuhan dan selalu semangat menjalankan ibadah puasa. Saat salah satu model mengeluhkan kondisi macet yang dialaminya gambar yang diperlihatkan justru semangat anak-anak panti yang sedang mempersiapkan segala keperluan sekolanya sendiri. Kemudian, saat model perempuan mengeluhkan kegiatan ngabuburitnya di mall, pembuat iklan memberikan gambaran berbanding terbalik di mana anak panti hanya menghabiskan waktu ngabuburitnya dengan menonton tv dan dilanjutkan mengaji bersama menjelang waktu berbuka puasa. Saat model pria mengeluhkan makanan yang jadi menu buka puasanya, anak-anak di panti terlihat semangat mempersiapkan menu untuk berbuka dan saat waktu berbuka mereka sangat menikmati menu buka puasa yang sangat sederhana.

Di dalam menjalankan ibadah Puasa Ramadan, ada beberapa syarat, rukun, dan amalan-amalan yang harus dilakukan. Syarat berpuasa di antarannya 1) Islam, 2) Baligh, 3) Berakal sehat, dan 4) Mampu melaksanakan puasa. Dan, rukun berpuasa yang harus dilaksanakan selama berpuasa di antaranya 1) Niat dalam hati. Puasa dianggap tidak sah tanpa disertai dengan niat yang dilakukan di malam hari sebelum subuh (terbitnya fajar), 2) Menahan diri dari makan dan minum walaupun sedikit, 3) Menahan diri dari jimak (melakukan hubungan intim dengan suami/istri), serta 4) Menahan diri dari muntah yang disengaja.

Adapun amalan-amalan puasa yang perlu dilaksanakan, di antaranya: 1) sahur walaupun dengan seteguk air, 2) menyegerakan berbuka (takjil), 3) berdoa ketika akan berbuka, 4) menahan anggota tubuh untuk tidak melakukan hal hal yang bisa mengurangi pahala puasa, 5) berusaha untuk mandi janabah atau mandi setelah haid atau nifas sebelum fajar, agar puasanya sejak pagi sudah dalam keadaan suci, walaupun jika mandinya dilakukan setelah fajar tetap puasanya dianggap sah, 6) memberi makan pada orang lain untuk berbuka puasa, baik makanan ringan, minuman atau lainnya, walaupun yang lebih utama adalah yang mengenyangkan, dan 7) itikaf, terutama pada sepuluh hari yang terakhir di bulan Ramadan. 
Berdasarkan syarat, rukun, serta amalan-amalan selama berpuasa Ramadan, iklan Teh Botol Sosro versi Ramadan ini mengajak kaum muslim agar melaksanakan segala yang menjadi ketentuan dalam beribadah Puasa Ramadan. Seperti yang terlihat di dalam adengan saat waktu berbuka puasa, anak panti asuhan menyegerakan berbuka dengan berdoa dan dilanjutkan menyantap hidangan pembuka (takjil : kolak) terlebih dahulu serta diakhiri dengan menimum Teh Botol Sosro. Selain itu, Hikmah puasa adalah memberikan pelajaran bagi si Kaya untuk merasakan lapar sehingga menumbuhkan rasa kasih sayang kepada fakir miskin. Hal ini terlihat di detikdetik akhir tayangan pada kalimat "Bagi sedikit yang kalian miliki untuk mewujudkan sedikit harapan mereka",

\section{c. AQUA versi Kemerdekaan RI (Rangkul Kebaikan)}

Slogan : \#RANGKULKEBAIKAN : Beli 2 botol AQUA, Dukung untuk Pendidikan Indonesia

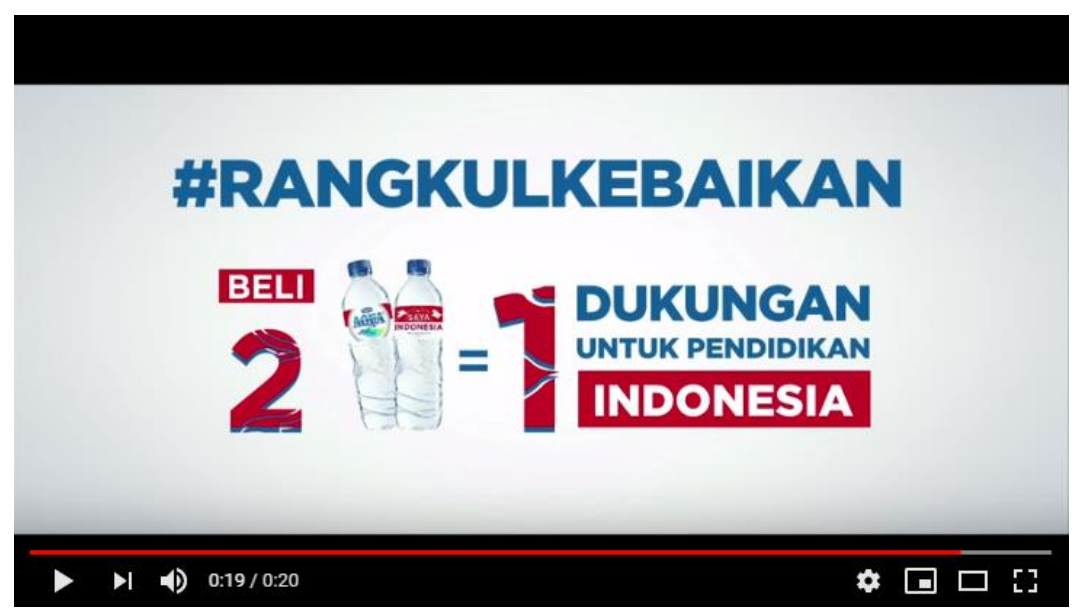

Dilihat dari adegannya, iklan ini ditunjukan kepada semua masyarakat dari berbagai usia dan pekerjaan seperti diperlihatkan pada iklan tersebut. Iklan ini memperlihatkan sekumpulan masyarakat dengan beragam usia dan pekerjaannya bersama-sama menyanyikan lagu dari iklan tersebut yang berisi ajakan berbuat kebaikan. Iklan ini diambil saat siang hari di salah satu kota di Indonesia. Suasana yang terlihat sangat hangat, di mana semua masyarakat bersama-sama untuk menjadi lebih baik salah satunya seperti berikut . Dilihat dari segi penggunaan bahasa, iklan ini menggunakan bahasa iklan pada umumnya seperti yang dinyanyikan. Pembuat iklan memasukan unsur ajakan yang ditandai dengan kata “ayo”. 
Berdasarkan data analisis dari Badan Pendidikan Dunia (UNIESCO) bahwa mutu pendidik di Indonesia berada pada peringkat terakhir di bawah Vietnam dari 14 negara di Asia Pasifik. Adapun untuk minat membaca, masyarakat Indonesia menempati posisi 39 dari 42 negara berkembang di dunia. Kemudian, kemampuan literasi bangsa Indonesia menduduki peringkat 61 dari 63 negara di dunia. Hal ini tidak lepas dari pengaruh faktor geografis wilayah Repulik Indonesia yang berbentuk kepulauan yang penyebaran tenaga pendidik (guru) serta sarana dan prasarana yang belum merata terutama pada sekolah di daerah terdepan, terluar, dan tertinggal. selain itu, faktor infastruktur di daerah 3T (terdepan, terluar dan tertinggal) yang menjadi penghambat meratanya pendidikan di Indonesia.

Melihat kondisi ini, pada Iklan AQUA versi Kemerdekaan RI (Rangkul Kebaikan) Dukung Pedidikan Anak Indonesia ingin mengajak masyarakat Indonesia untuk membantu pendidikan anak Indonesia dengan cara membeli 2 botol AQUA sama dengan 1 dukungan untuk pendidikan Indonesia. Produk AQUA merupakan pelopor air minum mineral dalam kemasan di Indonesia yang ingin berkontribusi untuk meningkatkan pendidik di Indonesia khususnya di daerah 3T (terdepan, terluar, dan tertinggal). Terlihat dalam iklan tersebut beberapa anak usia SD di daerah Indonesia bagian Timur tidak mengenakan pakaian sekolah sedang bersama para model iklan lainnya bernyanyi slogan “bersama rangkul kebaikan”. Melalui program yang ditawarkan, mengajak seluruh masyarakat Indonesia untuk membantu pendidikan anak Indonesia menjadi lebih baik.

\section{d. Sprite Versi Ramadhan}

Slogan : Sprite nyatanya nyegerin

"Hey guys, ayo berpikir jernih!

Apa iya Cuma liat air dikit aja bisa ganggu puasa kamu?

Meskipun adegan minum Sprite udah diilangin, ga gampang bikin iklan minuman di bulan puasa.

Nyatanya, haus jangan bikin semangat puasa pupus.

Sampai ketemu habis buka ya guys!

Sprite, nyatanya nyegerin.

Tapi kalau sudah buka." 


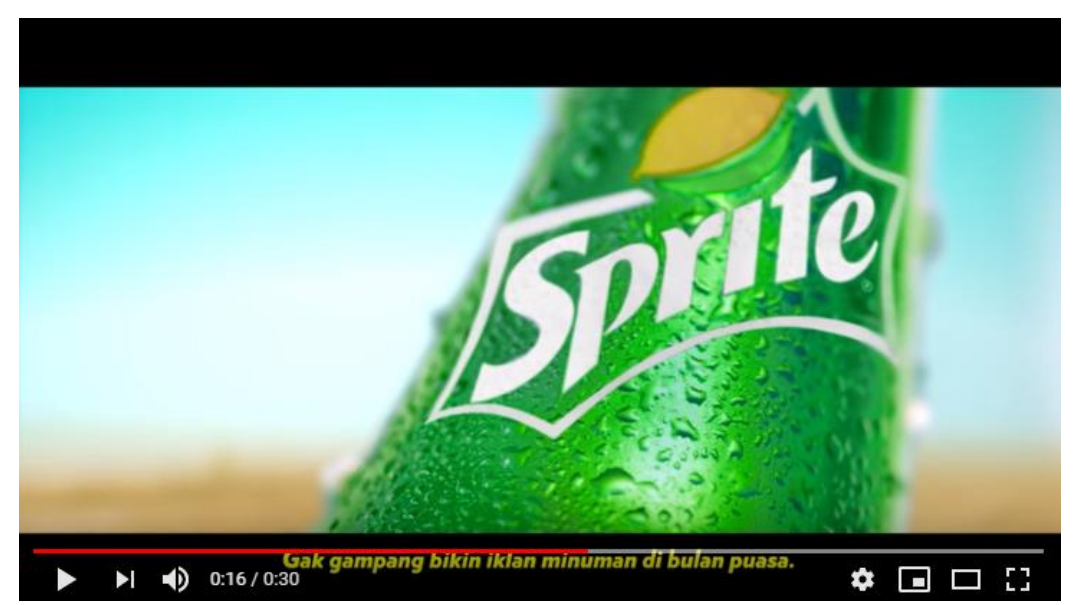

Situasi yang terlihat dari iklan Sprite bertempat di suatu padang safana yang gersang. Pada iklan ini digambarkan cuaca yang sangat terik yang dialami oleh seorang pengembala saat harus mengembala sapinya di Bulan Ramadan. Ketika model pada iklan tersebut melihat air yang mengalir dari selang berwarna hijau dia membayangkannya bahwa itu adalah sprite yang sangat segar. Namun berkat keimanan yang kuat penggembala tersebut memilih untuk melanjutkan puasanya.

Minuman bermerek Sprite ini adalah salah satu minuman bersoda yang mampu menyegarkan di segala situasi baik di siang hari maupun di malam hari ketika berbuka puasa sekalipun. Hal ini ditandai ketika adegan di mana penggembala tersebut akan meminum Sprite nya di siang hari tetapi dia menyimpan kembali dan menjadikannya sebagai minuman untuk berbuka puasa, berikut gambaran jelasnya. Selain mengajak para penonton untuk membeli produknya, pembuat iklan memasukan unsur ajakan lain yang mampu memotivasi dan membanggakan, yakni agar para penonton tidak membatalkan puasanya hanya karena melihat iklan ini.

Menyambut bulan Ramadan, iklan sprite versi Ramadan ini mencoba untuk menghimbau bagi umat muslim yang menjalankan ibadah puasa agar menjalankan segala ketentuan anjuran-anjuran dan larangan-larangan-Nya. Anjuran-anjuran serta larangan puasa di Bulan Ramadan ini mengacu pada Alquran serta hadis-hadis. Bagi umat muslim, puasa pada hakikatnya adalah menahan atau mengendalikan diri. Puasa sama halnya dengan sikap sabar. Kesabaran dalam mengendalikan diri saat berpuasa dalam iklan tersebut ditandai dengan kata-kata yang diucapkan secara monolog dalam kalimat 
berikut, "meskipun adegan minum Sprite udah diilangin, ga gampang bikin iklan minuman di bulan puasa. Nyatanya, haus jangan bikin semangat puasa pupus. Sampai ketemu habis buka ya guys!"”.

Allah berfirman surat Al-Baqarah 2 : 183, "Hai orang-orang yang beriman, diwajibkan atas kamu berpuasa sebagaimana diwajibkan atas orang-orang sebelum kamu agar kamu bertakwa."

Maksud dari surat Al-Baqarah 2: 183 menunjukkan bahwa tujuan berpuasa adalah agar tercapai ketakwaan. Ibadah puasa yang dikerjakan dengan sebenarnya akan menghantarkan seseorang pada ketakwaan. Ketakwaan yang didapat sebagai pengantar seseorang untuuk mendapatkan kesuksesan/keberhasilan. Selain itu, manfaat lain dalam menjalani puasa adalah kesehatan secara fisik terhadap tubuh, atau manfaat bagi kehidupan bermasyarakat.

\section{e. You C1000 versi Iris Mittenaere (Miss Universe 2016)}

Slogan : Healty inside, fresh out side

"Di Indonesia, masyarakat saling membantu satu sama lain saat perayaan pernikahan. Di saat persiapan untuk acara spesial bisa membuat tubuh dan pikiran terasa melelahkan bagi pasangan yang berbahagia.Penting bagi mereka untuk tetap sehat.

Untuk pengantin wanita, kecantikan yang sesungguhnya berasal dari dalam dan dimulai dengan tubuh yang sehat.Maka, apakah arti pernikahan tanpa pengantin yang cantik? Minum You C1000 vitamin dengan $1000 \mathrm{mg}$ vitamin C untuk menjaga daya tahan tubuh dan tetap sehat. Healty inside, fresh out side"

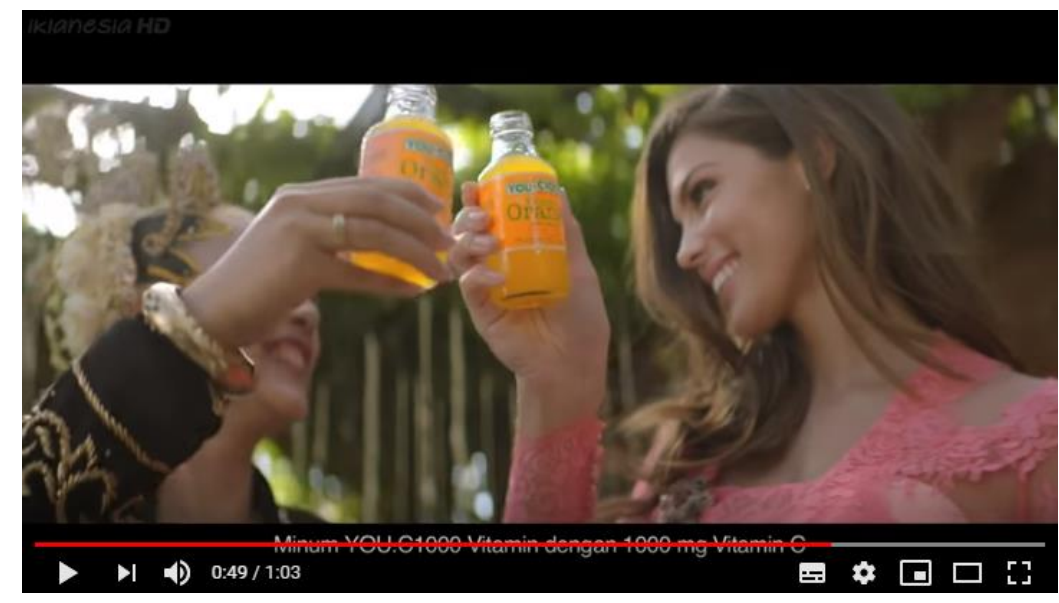

Konteks yang tergambar pada iklan ini ialah memperlihatkan beberapa kegiatan yang dilakukan sebelum dan saat acara pernikahan di berbagai daerah 
di Indonesia berlangsung. Pada iklan ini pembuat iklan memperlihatkan tiga pengantin dengan gaya dan konsep pernikahan yang berbeda-beda, ada yang menggunakan konsep adat Bali, Jawa serta yang ada juga yang menggunakan konsep Internasional. Iklan ini juga memperlihatkan kebersamaan dan kekeluargaan yang sangat akrab di berbagai daerah di Indonesia . Iklan ini memperlihatkan rasa saling tolong menolong masyarakat Indonesia salah satunya untuk mempersiapkan acara pernikahan. Latar yang diambil pada iklan ini ialah di berbagai tempat seperti Bali, Jawa, pantai, sawah, taman, rumah dengan waktu siang dan sore hari. Iklan ini disampaikan dalam bentuk monolog berbahasa Inggris yang kemudian diterjemahkan ke dalam bahasa Indonesia. Model pada iklan ini ialah Irish Mittenaere yang merupakan Miss Universe tahun 2016.

Secara kontekstual iklan ini memiliki makna bahwa seorang pengantin wanita haruslah cantik di hari pernikahannya dan untuk kecantikan seorang wanita sendiri bukan hanya dilihat dari luarnya saja tetapi dari dalam tubuh juga dengan memberikan asupan yang baik untuk tubuh dan kulit. YOU C 1000 merupakan minuman dengan kandungan vitamin C 1000 mg yang dipercaya dapat membantu menjaga daya tahan, kesehatan kulit dan manfaat lainnya bagi tubuh. Sehingga maksud kontekstual dari iklan ini ialah untuk memberitahukan kepada khalayak umum bahwa produk YOU C 1000 merupakan minuman yang baik karena memiliki kandungan vitamin yang sangat dibutuhkan oleh tubuh manusia baik untuk daya tahan maupun kecantikan kulit, makna ini diperkuat oleh gambar yang memperlihatkan saat model iklan meminum YOU C 1000 dengan menjelaskan pula kandungan di dalamnya. Dari segi penggunaan iklan sudah menggunakan bahasa iklan pada umumnya yang bersifat imperatif, persuasif dan memberikan informasi di dalamnya. Pada iklan ini pembuat iklan memberikan informasi mengenai cara hidup sehat dengan memberikan informasi kandungan dari YOU C 1000. Selain bertujuan untuk menjual produk yang diiklankan, iklan ini mengajak para penonton untuk melestarikan budaya Indonesia dan memperkenalkan budaya Indonesia ke mata dunia 


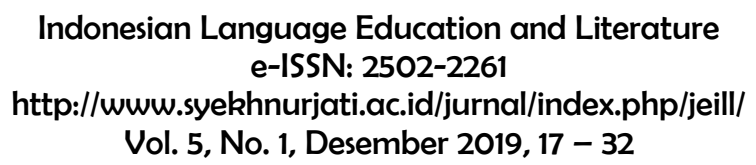

\section{SIMPULAN}

Makna tidak selalu berkaitan dengan dunia dalam bahasa saja, melainkan dari luar dunia bahasa pun dilihat keberadaannya. Penelitian ini dilakukan dengan memfokuskan pada konteks serta bahasa pada makna iklan. Telaah makna kontekstual dapat dilakukan jika ada unsur situasi dan penggunaan bahasa pada iklan itu sendiri. Berdasarkan hasil analisis makna kontekstualnya, bahwa iklan yang dibuat tidak terlepas dari adanya pengaruh konteks. Di samping memiliki nilai komersil, iklan yang dianalisis mengajak kepada khalayak untuk melakukan pada hal kebaikan.

\section{UCAPAN TERIMA KASIH}

Peneliti mengucapkan terima kasih kepada produsen Le Mineral, Aqua, Teh Botol, Sprite,You C100 yang telah mengunggah iklan produknya pada situs berbagi video youtube. Selain itu, kami mengucapkan terima kasih pada situs berbagi video youtube sehingga dapat memudahkan peneliti untuk mencari data yang diinginkan dengan cara mengunduh video akan dianalisis berdasarkan kajian kontekstual.

\section{DAFTAR PUSTAKA}

Aminuddin. (2013). Pengantar Apresiasi Karya Sastra. Bandung: Sinar Baru Algensindo.

Andrianto, N. (2018). Pesan Kreatif Iklan Televisi Ramadan 2017: Analisis Isi Iklan "Bahagianya Adalah Bahagiaku”. Jurnal Studi Komunikasi, 2(1), 17 -31 .

Azhari, M. Z. (2014). Analisis Semiotika Makna Pesan Moral dalam Iklan Sampoerna Versi "Orang Pemimpi” Di Televisi. Jurnal Ilmu Komunikasi, 2(3), $150-164$.

Chaer, A. (2009). Pengantar Semantik Bahasa Indonesia. Jakarta: Rineka Cipta.

Hendrastuti, R. (2015). Variasi Penggunaan Bahasa Pada Ruang Publik Di Kota Surakarta. Kandai, 11(1), $29-43$.

Jauhar, A. M. H. (2013). Makna Kontekstual Kata Sifat Amai dalam Lagu Jepang. GoKen, 1(1), $27-41$. 
Juniarti, I. W. \& Wahyuniarti, F. R. (2019). Makna Kontekstual dalam Novel Pasukan Matahari Karya Gola Gong. Sastranesia, 7(1), 54 - 67.

Kosasih, E. (2014). Jenis-Jenis Teks (Analisis Fungsi, Struktur dan Kaidah Kebahasaan Serta Langkah Penulisannya. Bandung: Yrama Widya.

Kuspriyono, T. (2015). Penggunaan Gaya Bahasa Pada Iklan Web PT L'oreal Indonesia. Jurnal Komunikasi, 6(1), 1 - 9.

Musaffak. (2015). Analisis Wacana Iklan Makanan dan Minuman pada Televisi Berdasarkan Struktur dan Fungsi Bahasa. Kembara, 1(2), 224 - 232.

Palimbong, D. R. (2015). Makna Kontekstual Dalam Novel Diary Pramugari Karya Agung Webe. Jurnal KIP 4(2), 915 - 926.

Parera, J. D. (2004). Teori Semantik. Jakarta: Erlangga.

Poluan, J. G., Genita G.L., \& Victoria N. U. (2016). Pengaruh Periklanan Terhadap Keputusan Pembelian Minuman Coca Cola (Studi Kasus Pada PT. Bangun Wenang Beverage Company Manado). Jurnal EMBA 4(3), 671 -681 .

Sugiantomas, A., Jaelani, A. J., \& Supriatna, A. N. (2017). Humor Jui Purwoto, Cak Lontong, Pandji Pragiwaksono, dan Ernest Prakasa dalam Stand Up Comedy (Analisis Makna Kontekstual, Makna Konseptual, dan Teori Humor dalam Kalimat Humor). Jurnal Fon, 10(1), 1 - 10.

Sukirno, S., et al. (2004). Pengantar Bisnis. Jakarta: Kencana Prenadamedia Group.

Sungkrajap, M. A. (2013). Analisis Pengaruh Atribut Iklan Televisi Terhadap Ekuitas Merek. Jurnal Maksipreneur 2(2), 80 - 100.

Suryanti. (2018). Makna Kontekstual Bahasa Iklan Rokok Di Televisi. Jurnal ASAS, 7(1), $49-51$.

Sutiyono, J. \& Sutrimah. (2016). Analisis Teks dan Konteks Pada Iklan Operator Seluler (XL dengan Kartu AS). Jurnal Pedagogia. 5(2), 297 - 310.

Tasruddin, R. (2015). Strategi Promosi Periklanan yang Efektif. Al-Khitabah, 2(1), $107-116$.

Wijayanto, A. (2015). Makna Konseptual dan Makna Asosiatif Dalam Teks Lagu Sheila On 7. Jurnal Sastra Indoneisa, 4(1), 1-10. 